\title{
Theoretical Issues for a Study of Missouri Public School Principals: Art Experiences and Attitudes Toward Art Education
}

\author{
Mick Luehrman
}

In Experience and Education, John Dewey wrote, "every experience affects for better or worse the attitudes which help decide the quality of further experiences, by setting up certain preference and aversion, and making it easier or harder to act for this or that end" (Dewey, 1938/1959, p. 29-30). This statement summarizes the theoretical foundation for the present study. Arthur Efland, in effect applying Dewey's idea directly to art education, wrote, "What people believe about art and its value is likely to affect whether it is taught or not" (Efland, 1995, p. 26).

The school principal is a key player in regard to the issue of how art education is delivered. According to Brent Wilson's findings in The Quiet Evolution (Wilson, 1997), art teachers and classroom teachers who attempt to establish comprehensive art programs without the support of the building administrator are not likely to succeed. Because of their responsibilities for the allocation of class time, funds and facilities, it is valuable to know how principals view art education and how their attitudes toward art education may have been formed.

For the present study, a questionnaire was sent to a representative sample of elementary, middle school/junior high, and high school principals in the state of Missouri. This instrument asked them to provide information about their art experiences in a variety of social contexts: during their own schooling, during their youth in the home and with family, with peers, with professional colleagues, and during adult leisure time. Seventy-nine percent (233) of the questionnaires were returned, and the data is in the process of being analyzed at this time. In addition, follow-up interviews were conducted with 6 selected volunteers in order to provide a thicker description of the phenomena.

Three foundational concepts guided this study: the nature of attitude and attitude toward art, Dewey's conception of experience, and the concept of crystallizing experience.

\section{Attitude and Art}

\section{The General Characteristics of Attitude}

Morris and Stuckhardt (1977) identified six generally agreed upon characteristics of attitude in their review of research on the subject. First, attitudes are affective evaluative concepts giving rise to motivated behavior; our attitudes affect what we say and do. Second, attitudes are learned, not innate, and therefore can be taught or altered. Direct contacts or experiences with the 
attitudinal referent have the greatest impact on attitudes. An example of this might be the difference between viewing a work of art in person as opposed to a slide in an art appreciation class, or a reproduction in an art textbook.

The third characteristic of attitudes is that they have specific social referents; they reflect the social context in which they are acquired (Morris \& Stuckhardt, 1977). They are acquired through socially mediated contacts with the attitudinal referent. The social mediators for an individual's contact with the world are often family members, teachers, or peers (Morris \& Stuckhardt, 1977). Keeping in mind that the social mediator for an art experience comes to the interactive encounter with a particular background and socially influenced position, one can see how social mediation might alter the experience of viewing or creating a work of art.

Fourth, attitudes are relatively stable and enduring. They are not easily changed once they are formed. This idea is congruent with characteristic number five, the idea that attitudes are interrelated, forming a network. In this way, one attitude supports another, a concept that explains the stability of attitudes and their resistance to change.

The sixth characteristic of attitudes is that they vary in quality; they may be positive or negative and differ in intensity or strength. This characteristic supports an understanding of why some attitudes might be more easily formed or altered than others.

Having examined the general characteristics of attitude, what is an art attitude? Morris and Stuckhardt define attitude toward art as, "A learned and relatively enduring evaluative system of affective predisposition held toward art referents" (1977, pp. 21-22). For the present study the art referent was art education, and the interest was in the ways in which Missouri public school principals' art experiences were related to their attitude toward this domain.

\section{Social Theories of Personality Formation}

Because they recognize the importance of social context and interaction, the characteristics of attitudes identified above are congruent with social theories of personality formation such as those associated with Vygotsky, Leontyev, and Bourdieu (Burkitt, 1991; Morris \& Stuckhardt, 1977). lan Burkitt sums up the essence of these theories and the connection to attitude formation when he states that "adults are the conductors of the socio-historical world through which the child forms its own self" (Burkitt, 1991, p. 137). Knowledge is handed down to us; it is socially derived through contact with domains of experience that are most often mediated by others: peers, teachers, parents, or other adults (Morris \& Stuckhardt, 1977; Zurmuehlen, 1979). For this reason it was important in the present study to examine a variety of social contexts for experiences that were related to attitude toward art education. 


\section{Experience}

\section{An Experience vs. Experience in General}

How does an experience differ from experience in general? According to Dewey an experience occurs when, "material runs its course to fulfillment" (1938/1956 p. 4). An experience is an episode, exemplified by an event such as viewing or creating a work of art. Like a story, an experience has a beginning, middle, and an end; it is discrete within the stream of general experience and set apart. According to Dewey (1938/1959), among the characteristics of an experience are the following: (1) It is transactional, or interactive, involving our interaction with the world of people and objects; (2) It is temporal, it has a history, it takes place within a time frame; (3) It has continuity; an experience is affected by what has happened and what will happen.

Transposing the concept of experience into the realm of education, Dewey (1938/1959) introduced and Eisner (1985/1997) reaffirmed the concept of the educative qualities of experience: the idea that experiences can be educative, noneducative, or miseducative. Educative experiences are those that stimulate interest, encouraging and allowing for further growth and expansion within a domain. They promote the formulation of positive attitudes (Dewey, 1938/1959; Morris \& Stuckhardt, 1977). What follows is a quote from a respondent who described a particular art experience he felt had a significant positive impact on his attitude toward art education:

As an eighth grader we did the following: wood sculpture, copper tooling, paper jewelry, and ceramics. I have always remembered that experience and still have the copper tooling mask and ceramic bust I created. As a principal, once in a while I sit in and do the project along with the students.

Non-educative experiences have essentially no impact. They are not as likely to be memorable, and might be exemplified by daily routines such as the drive to work or eating breakfast. Miseducative experiences limit or shut off possibilities for further growth within a domain, conceivably perpetuating misconceptions about and alienation from the attitudinal referent. In the quote that follows, a respondent in the present study described a particular art experience that she believed had a negative impact on her attitude toward art education:

Sitting in elementary classes when every Friday afternoon the teacher said it was art time. She would give us paper and crayons. Next, she would say, "draw a picture of whatever you want." I seemed to always have difficulty coming up with something creative to draw. I would draw a blank as to ideas and would end up drawing a tree that didn't look like a tree with clouds, flowers, birds and a house. So simplistic! Never was the teacher inclined to use motivational strategies for generating ideas. Usually, the teacher used this time to grade papers to do lesson plans for the following week. 
The idea that a particular experience, such as the one above, may be defining moments for the individual is related to what Howard Gardner (1983) calls crystallizing experiences.

\section{Crystallizing Experiences}

The concept of crystallizing experiences is one primarily associated with research in the area of the gifted and talented, particularly Howard Gardner's work with colleagues at project zero, seeking pivotal events that identify precocious talent in a specific domain (Gardner, 1983; Gardner, 1993; Walters \& Gardner, 1984). However, Cameron, Mills, \& Heinz in their 1995 study of talented youths offer a definition for crystallizing experiences that is wider in scope, calling them "experiences which solidify the individual's awareness of some aspect of the self" (1995, p. 197). In their instructions to participants in the study, they acknowledge the negative as well as the positive connotations of crystallizing experiences:

You might recall a crystallizing experience when you discovered you had an interest or talent in painting, chemistry, music, mathematics, or writing. Or, you may have concluded that you really were not good at something. (Cameron, Mills, \& Heinz, 1995, p. 198).

Anecdotal evidence from the writings of preservice elementary teachers at the University of Missouri-Columbia presented examples of both positive and negative school art experiences that remained strongly ingrained in students' minds as they began an art methods class:

I had a wonderful experience in appreciation of art (here at M. U.), my teacher was great, she was so, so insightful, she brought a whole new meaning of art to me. To this day because of her I view art in a different new and exciting way (Luehrman, 1998 n. 1).

I have never thought that I have been very good at art. In third grade we made witches for Halloween and I forgot to put my name on mine. My teacher held it up and asked who had not put their name on it and then she made fun of my witch because I could not cut it out straight (Luehrman, 1998, p. 1).

Interviews with public school administrators in South Carolina (Colbert, 1997) offered additional examples of miseducative art experience such as this:

The elementary art methods course I had in undergraduate school did not prepare me to make decisions about art education. It was a media-oriented class, taught by a reluctant art studio faculty member-not an art educator... we all sensed that teaching our course was his punishment--and ultimately ours too (Colbert, 1994, pp. 6-7).... It was a joke... We made our little ash trays...

The idea that either a negative experience or a positive experience within a domain could be pivotal for the formation or maintenance of attitude is an idea that 
is central to the present study.

\section{Personal meaning and social context crystallizing experience}

Rather than the apparent attributes of an experience, it is the meaning one attaches to it that is most important. Cameron, Mills, and Heinz state that "Crystallizing experiences may be big and life changing, or small but meaningful" (1995, p. 198). An event that seems insignificant to one individual could be important in its effect on another. Evidence from other studies indicates that there may be no set pattern for when or where meaningful experiences take place, though the cultural climate of the home and arts activities during youth seem to have the strongest effect (Ganzeboom, 1996; Haanstra, Oud, Nagel, \& Ganzeboom, 1997). Because of this, it is important for the present study to look for art experiences that are meaningful to the individual within a variety of social contexts: childhood and adulthood, family and school

\section{Domain-defining experiences}

Anecdotal evidence makes it seem likely that many individuals have individual experiences or groups of experiences (both positive and negative) in art and art education which come to define this domain for them. For some, these experiences may be of a lesser intensity than the crystallizing experiences which Gardner and his colleagues are seeking in their research, but when identified by participants as experiences that stand out in their memory they would seem to be of some importance in the shaping of attitude. In this situation, rather than crystallizing experiences they might more accurately be referred to as domain-defining experiences.

If attitudes toward art education are initially formed by these types of art experiences, it would seem that those who continue to choose to take part in art activities during their leisure time would have tended to have positive attitudes toward art and art education. This idea is related to the flow theory of Mihaly Csikzsentmihalyi (1997).

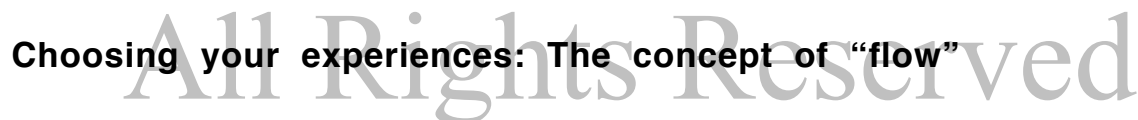

Csikzsentmihalyi's flow theory (1997) attempts to answer the question of why individuals choose to invest time and energy in certain activities over others. It promotes the idea that what an individual chooses to do is a reflection of who they are. Csikzsentmihalyi believes that we are most fulfilled when engaged in activities that place us in what he calls a state of flow, somewhere between boredom and anxiety: a place where we are challenged yet we feel with reasonable certainty that we are on our way to success. The positive experiences we have may help us identify the areas in which we are likely to experience flow (Csikzsentmihalyi, 1997). Choosing to participate in art activities, either art-making or art-viewing, during leisure time would seem to be a likely predictor for positive attitude toward art and art education, and may also likely be the consequence of earlier positive domain-defining experiences in art and art education. 
Though the present study will not be able to address issues of causality, the researcher hopes to provide a baseline for further investigations by providing a comprehensive description of the art experiences of Missouri public school principles and looking for relationships between their experiences and attitude toward art education.

\section{Conclusion}

If Dewey's claim that, "every experience affects for better or worse the attitudes which help decide the quality of further experiences" (1938/1959, pp. 29-30) is accepted, then it follows that the art experiences that individuals have as they mature and pass through the educational system can affect not only their attitudes toward art education, but their actions as well. Students in art classes at all levels include those who will go on to fill all sorts of positions of responsibility in society, including educational leadership. The future credibility of art education is to some extent in the hands of art educators themselves through the domaindefining experiences that are provided for students.

\section{References}

Bourdieu, Pierre (1972/1977). Outline of a theory of practice. (English language translation by Richard Nice). Cambridge, Great Britain: Cambridge University press

Burkitt, lan (1991). Social selves (Theories of the social formation of personality). London: Sage Publications.

Cameron, Patricia A.; Mills, Carol J.; Heinzen, Thomas E. (1996). The social context and development patterns of crystallizing experiences among academically talented youth, Roeper review, 17 (3), 197-200.

Colbert, Cynthia (1994) What you are doing speaks so loudly, I can't hear what you are saying: Higher education's legacy to art in the public schools. Paper presented at the Higher Education Division Meeting of the National Art Education Association, Baltimore, MD.

Csikszentmihalyi, Mihaly (1997). Activity, experiences and personal growth. In Curtis, James E. And Russell, Storm J. (Eds.) Physical activity and human experience (pp. 61-88). Champaign, IL: Human Kinetics.

Dewey, John (1938/1959). Experience and education. New York: MacMillan Company.

Dobbs, Stephen M. (1998). Learning in and through art. Los Angeles, CA: The Getty Education Institute for the Arts.

Efland, Arthur D. (1995). Change in the conceptions of art teaching. In Ronald Neperud (Ed.), Context, content and community in art 
education beyond postmodernism ( $\mathrm{pp}$ 25-40). New York: Teachers College Press.

Eisner, Elliot W. (1994). The educational imagination, 3rd edition. New York: MacMillan College Publishing.

Ganzeboom, Harry B. G. (1996). Effects of arts education in primary and secondary education on cultural consumption and socio-economic careers in later life. In, Art\&fact: Learning effects of arts education, (A collection of lectures given during the two day international conference, Art\&fact, March 27-28, 1995 in the World Trade Center, Rotterdam, the Netherlands) LOKV, Netherlands Institute for Arts Education, Utrecht, 1996.

Gardner, Howard (1983). Frames of mind: The theory of multiple intelligences. New York: Basic Books.

Gardner, Howard (1993). Multiple intelligences: The theory in practice. New York: Basic Books.

Haanstra, F., Oud, W., Nagel, I., \& Ganzeboom, H. (1997). Long-term effects of art examination programs in Dutch secondary schools, Paper presented at the AERA Annual Meeting, March 24-28, 1997, Chicago, IL.

Luehrman, Mick (1998). Comments by pre-service teachers about their past art experiences, Unpublished manuscript, University of Missouri, Columbia.

Morris, Jerry W., Stuckhardt, Michael H. (1977). Art attitude: Conceptualization and implication, Studies in Art Education, 19 (1), 21-28.

National Art Education Association (1992). Elementary art programs: A guide for administrators. Reston, VA: National Art Education Association.

Walters, Joseph; Gardner, Howard (1984). The crystallizing experience: Discovering an intellectual gift. Harvard project zero, report sponsored by Bernard Van Leer Foundation, The Hague (Netherlands), and Social Science Research Council, NY.

Wilson, Brent (1997). The quiet evolution. Lost Angeles, CA: The Getty Education Institute for the Arts.

Zurmuehlen, Marilyn (1979). A phenomenological viewpoint on meaning, Paper presented April 167, 1979, at the Seminar for Research in Art Education, National Art Education Association, San Francisco, California. 